\title{
Temperature Effect on Light Concentration Silicon Solar Cell's Operating Point and Conversion Efficiency
}

\author{
Mahamadi Savadogo, Boubacar Soro, Ramatou Konate, Idrissa Sourabié, \\ Martial Zoungrana, Issa Zerbo, Dieudonné Joseph Bathiebo
}

Laboratory of Thermal and Renewable Energies, Department of Physics, Unit of Training and Research in Pure and Applied Sciences, University Joseph KI-ZERBO, Ouagadougou, Burkina Faso

Email: savadogo.mahamadi1976@gmail.com

How to cite this paper: Savadogo, M., Soro, B., Konate, R., Sourabié, I., Zoungrana, M., Zerbo, I. and Bathiebo, D.J. (2020) Temperature Effect on Light Concentration Silicon Solar Cell's Operating Point and Conversion Efficiency. Smart Grid and Renewable Energy, 11, 61-72.

https://doi.org/10.4236/sgre.2020.115005

Received: May 8, 2020

Accepted: May 25, 2020

Published: May 28, 2020

Copyright $\odot 2020$ by author(s) and Scientific Research Publishing Inc. This work is licensed under the Creative Commons Attribution International License (CC BY 4.0).

http://creativecommons.org/licenses/by/4.0/

(c) (i) Open Access

\begin{abstract}
It is well known that temperature acts negatively on practically all the parameters of photovoltaic solar cells. Also, the solar cells which are subjected to particularly very high temperatures are the light concentration solar cells and are used in light concentration photovoltaic systems $(C P V)$. In fact, the significant heating of these solar cells is due to the concentration of the solar flux which arrives on them. Light concentration solar cells appear as solar cells under strong influences of heating and temperature. It is therefore necessary to take into account temperature effect on light concentration solar cells performances in order to obtain realistic results. This one-dimensional study of a crystalline silicon solar cell under light concentration takes into account electrons concentration gradient electric field in the determination of the continuity equation of minority carriers in the base. To determine excess minority carrier's density, the effects of temperature on the diffusion and mobility of electrons and holes, on the intrinsic concentration of electrons, on carrier's generation rate as well as on width of band gap have also been taken into account. The results show that an increase of temperature improves diffusion parameters and leads to an increase of the short-circuit photocurrent density. However, an increase of temperature leads to a significant decrease in open-circuit photovoltage, maximum electric power and conversion efficiency. The results also show that the operating point and the maximum power point $(M P P)$ moves to the open circuit when the cell temperature increases.
\end{abstract}

\section{Keywords}

Temperature, Electric Power, Conversion Efficiency, Light Concentration, Maximum Power Point, Junction Dynamic Velocity 


\section{Introduction}

The principle of light concentration photovoltaic systems $(C P V)$ is to concentrate, using parabolic mirrors or Fresnel lenses, the sunlight on a PV cell, to obtain higher conversion efficiency than those classic cells. This process, which is more recent, uses cell technologies which are more expensive but also more efficient than conventional cells [1]. These technologies used for space applications, must be installed in places which have a strong direct sunshine and require trackers to follow the course of the sun and thus collect as much direct light as possible [1] [2].

Among these light concentration solar cells, those which use multispectral conversion technology allow highest efficiency to be obtained [2]. Dimroth et al. [3] worked on four-junction solar cell of the GaInP/GaAs//GaInAsP/GaInAs type and showed that an increase of light concentration leads to an increase of open-circuit photovoltage, fill factor and conversion efficiency which reaches a value of $44.7 \%$ under $C=297$ Suns. Schachtner et al. [4], Tibbits et al. [5] have also worked on multi-junction cells and have obtained similar results.

However, the relatively high cost of these cells makes multispectral conversion a very expensive technology for large-scale adoption of photovoltaic energy [1] [2]. Pelanchon et al. [6] worked on crystalline silicon solar cell and demonstrated the need for high concentrations ( $C>50$ Suns) to take into account electrons concentration gradient electric field.

Several studies have been carried out taking into account the electric field of concentration gradient [7] [8] [9] and have shown the improvement of silicon solar cell's performances with increase of light concentration.

Many authors [10]-[20] have shown that temperature has harmful effects on all electronic and electrical parameters of a silicon solar cell. However, these authors did not work under concentrated light. Soro et al. [21] worked under concentrated light but did not take into account temperature effect on carrier's intrinsic concentration, on the band gap width and on the diffusion coefficients of electrons and holes.

Wang et al. [22] have shown that increasing the concentration of light accentuates the effect of temperature on the parameters of the cell.

In this work, we take into account temperature influence on: mobility and diffusion coefficients of electrons and holes, the intrinsic concentration of carriers, the carrier's generation rate and the width of band gap. We study temperature effect on diffusion parameters and electrical parameters such as photocurrent density, photovoltage, electrical power and conversion efficiency. We submit a crystalline silicon solar cell to concentrated light ( $C=50$ Suns) and we take into account electrons concentration gradient electric field.

\section{Theory}

\subsection{Excess Minority Carriers' Density}

Our study model is a silicon solar cell illuminated by a concentrated light under 
temperature influence as shown in Figure 1 below. We considered a silicon solar cell $\left(n^{+}-p-p^{+}\right)$operating under a concentrated multispectral light ( $C=50$ Suns) in the quasi-neutral base assumption [7] [8] [9]. Because of light intensity, carrier concentration in the base is not uniform. So, we take into account the electric field due to the difference of carrier concentration $E(x)$ which is given by Equation (1) [6] [7] [8] [9] [21]:

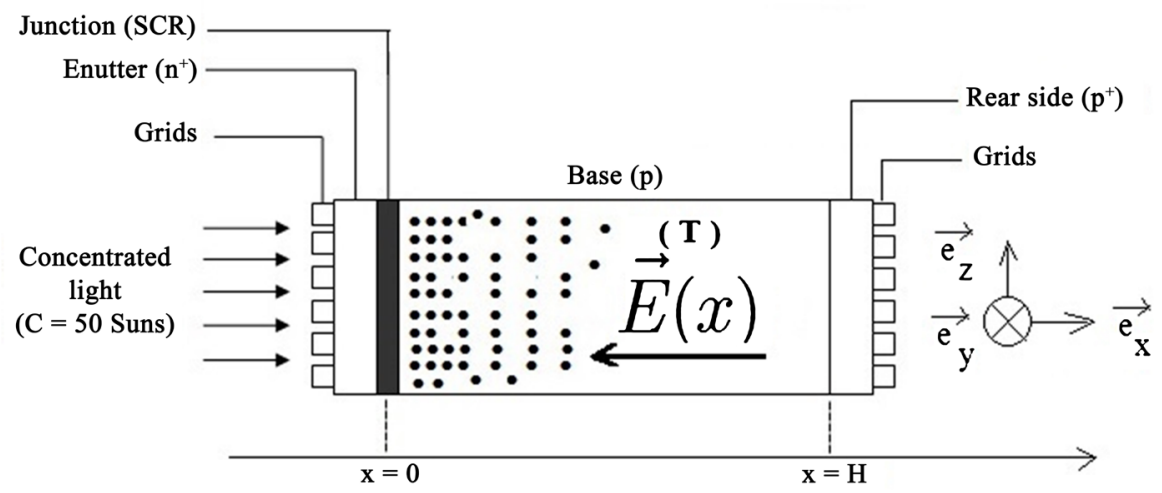

Figure 1. Silicon solar cell illuminated by concentrated light and under temperature influence.

$$
E(x)=\frac{D_{p}-D_{n}}{\mu_{n}+\mu_{p}} \cdot \frac{1}{\delta(x)} \cdot \frac{\partial \delta(x)}{\partial x}
$$

The distribution of excess minority carriers in the solar cell's base along the $X$ axis is given by:

$$
\begin{gathered}
\frac{\partial^{2} \delta(x, T)}{\partial x^{2}}-\frac{\delta(x, T)}{\left(L^{c}(T)\right)^{2}}=-\frac{G_{n}}{D^{c}(T)} \\
\text { with } D^{c}(T)=\frac{\mu_{n}(T)\left[2 D_{n}(T)-D_{p}(T)\right]+\mu_{p}(T) D_{n}(T)}{\mu_{n}(T)+\mu_{p}(T)}
\end{gathered}
$$

$D^{c}(T)$ represents the expression as function of temperature $T$ of diffusion coefficient in the base with the taking into account of the electric field of electrons concentration gradient. The expressions as functions of temperature of the mobility of electrons and holes respectively $\mu_{n}(T)$ and $\mu_{p}(T)$ are given by following equations [10]:

$$
\begin{gathered}
\mu_{m}(T)=\mu_{m}^{\min }(T)+\frac{\mu_{m}^{L}(T)-\mu_{m}^{\min }(T)}{1+\left(\frac{N_{m}}{N_{m}^{r e f}(T)}\right)^{a_{m}(T)}} \\
\mu_{m}^{L}(T)=\mu_{m, 300}^{L}\left(\frac{T}{300}\right)^{y_{0, m}} \\
\mu_{m}^{\min }(T)=\mu_{m, 300}^{\min }\left(\frac{T}{300}\right)^{y_{1, m}} \\
N_{m}^{r e f}(T)=N_{m, 300}^{r e f}\left(\frac{T}{300}\right)^{y_{3, m}}
\end{gathered}
$$




$$
a_{m}(T)=a_{m, 300}\left(\frac{T}{300}\right)^{y_{4, m}}
$$

In above equations, $m$ is the type of dopant material (type $n$ or type $p$ ). For this work the n-type dopant concentration of $N_{d}=10^{18} \mathrm{~cm}^{-3}$ and $p$-type of $N_{a}=10^{16} \mathrm{~cm}^{-3}$ was determined. We have, for:

- $m=n: \mu_{n, 300}^{L}=5300 \mathrm{~cm}^{2} / \mathrm{V} \cdot \mathrm{s}, \quad y_{0, n}=-19, \quad \mu_{n, 300}^{\min }=1520 \mathrm{~cm}^{2} / \mathrm{V} \cdot \mathrm{s}$, $y_{1, n}=-2, N_{d, 300}^{r e f}=64 \times 10^{16} \mathrm{~cm}^{-3}, y_{3, n}=37, a_{n, 300}=05, y_{4, n}=0$.

- $m=p: \mu_{p, 300}^{L}=200 \mathrm{~cm}^{2} / \mathrm{V} \cdot \mathrm{s}, \quad y_{0, p}=-1.2, \quad \mu_{p, 300}^{\min }=24 \mathrm{~cm}^{2} / \mathrm{V} \cdot \mathrm{s}$, $y_{1, p}=1.2, \quad N_{a, 300}^{r e f}=2.5 \times 10^{17} \mathrm{~cm}^{-3}, y_{3, p}=0.47, a_{p, 300}=1, y_{4, p}=0$.

Expressions of electrons and holes diffusion coefficient are given by the following equation [9]-[18]:

$$
D_{n, p}(T)=\frac{k T}{q} \mu_{n, p}(T)
$$

with $q$ the elementary charge, $k$ the Boltzmann constant. The generation rate $G_{n}$ is the sum of two contributions:

- The carrier photo-generation rate $G(x)$ at the depth $x$ in the base [6] [7] [8] [9] [21]

$$
G(x)=C \cdot \sum_{i=1}^{3} a_{i} \mathrm{e}^{-b_{i} x}
$$

Crepresents light concentration.

- The carrier thermal generation rate which is given by [23]:

$$
G_{t h}=C_{t h} \cdot n_{i}^{2}
$$

$C_{t h}$ is a proportionality coefficient and $n_{i}$ is the intrinsic concentration of minority carriers in the base which expression is given by [16] [23] [24]:

$$
n_{i}=A_{n} \cdot T^{\frac{3}{2}} \cdot \exp \left(-\frac{E g(T)}{2 k T}\right)
$$

$A_{n}$ is a specific constant of the material ( $A_{n}=3.87 \times 10^{16}$ for silicon). $N_{b}$ is the base doping concentration in impurity atoms [23] [24] and $\tau=\frac{1}{C_{t h} N_{b}} . E g$ represents the silicon band gap energy which variation with temperature is given for by [11] [12] [13]:

$$
\begin{gathered}
E g(T)=1.1557-\frac{7.021 \times 10^{-4} T^{2}}{T+1108} \\
G_{n}=G(x)+G_{t h}
\end{gathered}
$$

The excess minority carriers' density is determined solving continuity Equation (2):

$$
\begin{aligned}
\delta(x, T)= & A \operatorname{ch}(\alpha(T) x)+B \operatorname{sh}(\alpha(T) x)+\sum_{i=1}^{3} K_{i}(T) \cdot \mathrm{e}^{-b_{i} x} \\
& +\frac{\left(L^{c}(T)\right)^{2}}{D^{c}(T)} C_{t h} A_{n}^{2} T^{3} \exp \left(-\frac{E g(T)}{k T}\right)
\end{aligned}
$$




$$
\text { with } K_{i}(T)=\frac{C}{D^{c}(T)} \frac{a_{i}\left(L^{c}(T)\right)^{2}}{\left[1-\left(b_{i} L^{c}(T)\right)^{2}\right]} \text { and } \alpha(T)=\frac{1}{L^{c}(T)}
$$

Coefficients $A$ and $B$ are determined through the following boundary conditions:

- At the junction $(x=0)$

$$
\left.D^{c}(T) \cdot \frac{\partial \delta(x, T)}{\partial x}\right|_{x=0}=S f \cdot \delta(x=0, T)
$$

The junction dynamic velocity $(S f)$ is the sum of two contributions: the intrinsic junction recombination velocity $\left(S f_{0}\right)$ related to carriers losses at the junction and the junction dynamic velocity $\left(S f_{j}\right)$ that defines the operating point of the cell because it is the carriers' flow imposed by an external load resistance [18] [25]:

$$
S f=S f_{0}+S f_{j}
$$

- At the rear side $(x=H)$

$$
\left.D^{c}(T) \cdot \frac{\partial \delta(x, T)}{\partial x}\right|_{x=H}=-S_{b} \cdot \delta(x=H, T)
$$

The back surface recombination velocity $\left(S_{b}\right)$ quantifies the losses of carriers at the cell's rear side [18] [25]. In this work we studied a back surface field silicon solar cell and this kind of solar cell present low values of recombination velocity, so for this work we take $S_{b}=10^{2} \mathrm{~cm} / \mathrm{s}$.

\subsection{Photocurrent Density}

Applying Fick's law at the junction, we obtained the photocurrent density given by [7] [8] [9] [15] [25] [26]:

$$
J_{p h}(S f, T)=\left.q \cdot D^{c}(T) \cdot \frac{\partial \delta(x, S f, T)}{\partial x}\right|_{x=0}
$$

\subsection{Junction Photovoltage}

The photovoltage across the solar cell junction derives from the Boltzmann relation [7] [8] [9] [15] [25] [26]:

$$
V_{p h}(S f, T)=V(T) \cdot \ln \left[\frac{\delta(x=0, S f, T)}{n_{0}}+1\right]
$$

In this expression $V(T)$ represents the thermal voltage and $n_{0}$ is electrons density at thermodynamic equilibrium. We have $V(T)=\frac{k T}{q}$ and $n_{0}=\frac{n_{i}^{2}}{N_{B}}$; $n_{i}$ is intrinsic concentration of electrons.

\subsection{Electric Power Delivered by the Solar Cell}

The electric power delivered by the solar cell base to an external circuit expression is [8]:

$$
P(S f, T)=V_{p h}(S f, T) \cdot J_{p h}(S f, T)
$$




\subsection{Conversion Efficiency}

The solar cell's conversion efficiency is given by the Equation 18 [8]

$$
\eta(T)=\frac{P_{m}(S f, T)}{P_{i n c}}
$$

In this expression, $P_{\text {inc }}$ is the power of the incident concentrated light. For a light concentration solar cell and under Air Mass 1.5 standard conditions (1000 $\mathrm{W} / \mathrm{m}^{2}$ ), the proportion of light, which is concentrated, is around $720 \mathrm{~W} / \mathrm{m}^{2}$. Thus, for a 50 suns light concentration, $P_{\text {inc }}$ is assumed to be [8] [9]:

$$
P_{\text {inc }}=0.072 \mathrm{~W} / \mathrm{cm}^{2} \times 50=3.6 \mathrm{~W} / \mathrm{cm}^{2}
$$

\section{Results and discussion}

\subsection{Temperature Effect on Diffusion Parameters}

We plotted variations of diffusion coefficient and diffusion length, versus temperature as shown respectively in Figure 2 and Figure 3.

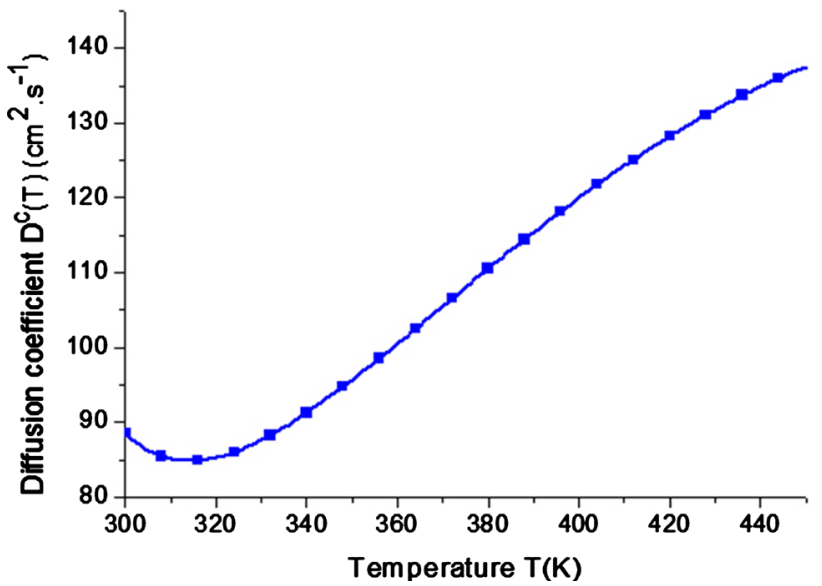

Figure 2. Temperature effect on diffusion coefficient.

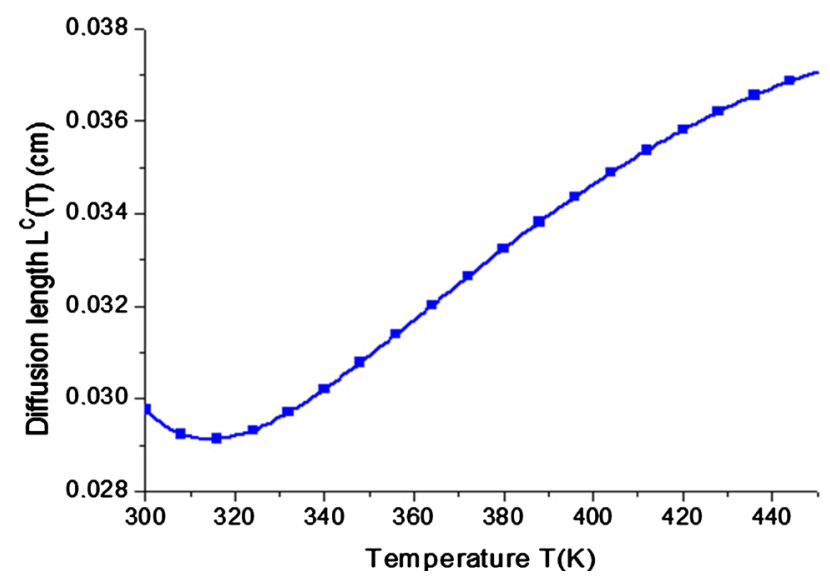

Figure 3. Temperature effect on diffusion length.

From $300 \mathrm{~K}$ to $314 \mathrm{~K}$, Figure 2 and Figure 3 show that diffusion parameters 
decrease. This behavior leads to a decrease of carriers flux through the junction and then a decrease in photocurrent density. This decrease of diffusion parameters with temperature leads also to the carrier's storage near the junction and to an increase of open circuit photovoltage. Carriers blocking near solar cell junction could also come with an increase of the recombination in volume.

However from $314 \mathrm{~K}$, the diffusion parameters increase with increasing temperature. This behavior leads to an increase of carriers flow through the junction and therefore an increase of short circuit current density as shown in Figure 4. The short circuit photocurrent density increase will have as a consequence, a decrease of carrier's density at the junction and therefore a decrease in photovoltage as shown in Figure 5.

The solar cell being under light concentration and therefore operating under high temperatures, in the rest of this work we'll only take into account the temperatures $T \geq 314 \mathrm{~K}$.

\subsection{Temperature Effect on Photocurrent Density}

Figure 4 illustrates the photocurrent density profile versus junction dynamic velocity imposed by an external load, for different values of temperature.

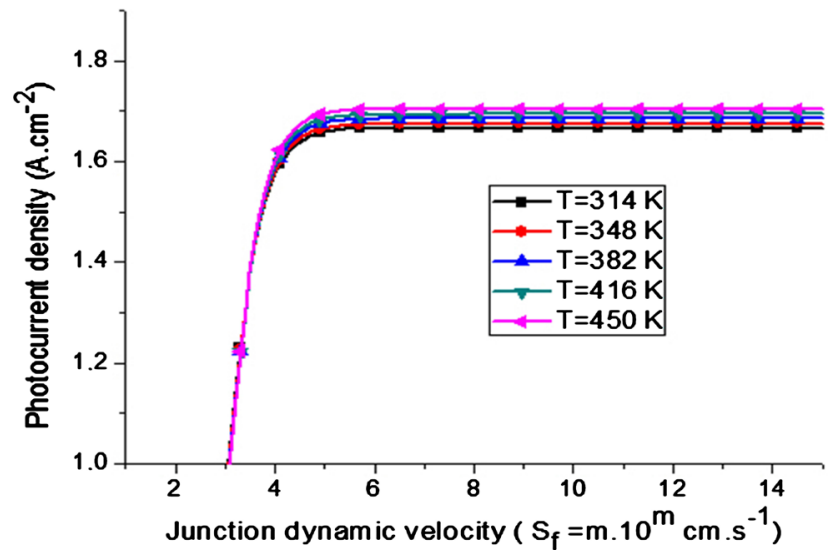

Figure 4. Photocurrent density versus junction dynamic velocity for different values of temperature ( $C=50$ Suns, $H=0.03 \mathrm{~cm}, S_{b}=10^{2} \mathrm{~cm} / \mathrm{s}$ ).

The curves in Figure 4 show that the effect of temperature on photocurrent density is noticeable only at large values of junction dynamic velocity $S f$. Thus, the increase of the temperature due to the solar cell illumination under intense light leads to an increase of short circuit photocurrent density $\left(J_{s c}\right)$. This increase of short-circuit photocurrent density with increase of temperature is in good agreement with increases of diffusion coefficient and diffusion length observed above for temperatures $T \geq 314 \mathrm{~K}$. This result is in good agreement with Agroui et al. [17] who worked under non-concentrated lighting with significantly lower temperature values.

\subsection{Temperature Effect on Photovoltage}

Figure 5 illustrates for different temperatures, photovoltage profile versus junction dynamic velocity $(S f)$. 


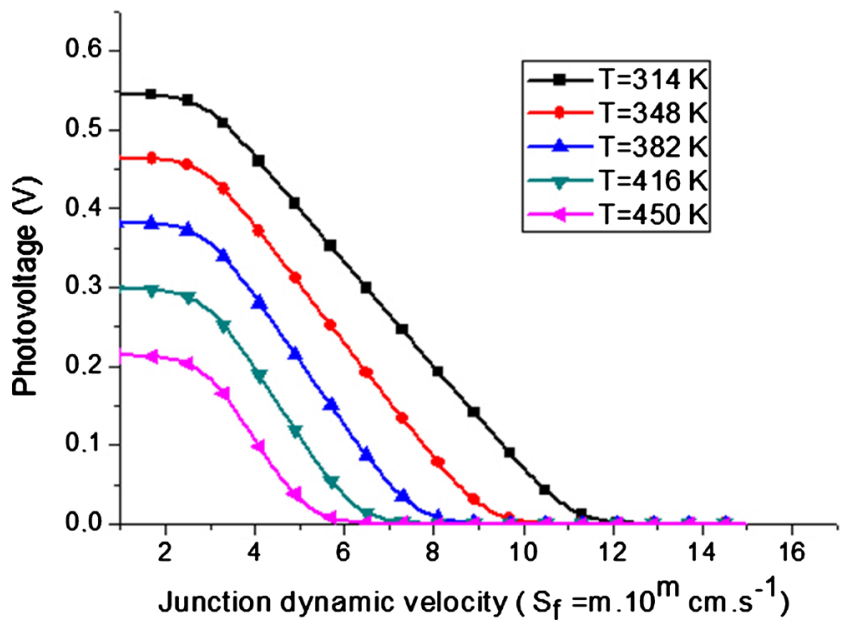

Figure 5. Photovoltage versus junction dynamic velocity for different values of temperature ( $C=50$ Suns, $H=0.03 \mathrm{~cm}, S_{b}=10^{2} \mathrm{~cm} / \mathrm{s}$ )

The curves in Figure 5 show a significant decrease of open-circuit photovoltage with an increase of temperature. This result is in accordance with the effect of the temperature on the diffusion parameters observed in Figure 2 and Figure 3: increase of diffusion parameters leading to an increase of carrier's diffusion through the junction. This result is in good agreement with those of Chander et al. [16] and Agroui et al. [17] who however worked under non-concentrated lighting and under relatively lower temperature values.

The curves also show that an increase of temperature leads to a decrease of the value of short circuit junction dynamic velocity $S f_{c c}$ corresponding to the null values of the photovoltage.

Table 1 below gives, for different temperatures, the value of short circuit junction dynamic velocity from which the photovoltage becomes null.

Table 1. Temperature values and junction dynamic velocity from which the photovoltage becomes null.

\begin{tabular}{cccccc}
\hline$T(K)$ & 314 & 348 & 382 & 416 & 450 \\
$S f_{c c}(\mathrm{~cm} / \mathrm{s})$ & $3.95 \times 10^{13}$ & $4.22 \times 10^{11}$ & $9.00 \times 10^{9}$ & $4.92 \times 10^{8}$ & $2.63 \times 10^{7}$ \\
\hline
\end{tabular}

These results confirm that the values of $(S f)$ from which the photovoltage becomes null decrease when the cell's temperature increases. This result corresponds to a displacement of the solar cell operating point towards the open-circuit when cell's temperature increase.

\subsection{Effect of Temperature on Electric Power}

Figure 6 show the variations in electric power versus junction dynamic velocity for different values of temperature.

The curves in Figure 6 show that an increase of temperature leads to a decrease 


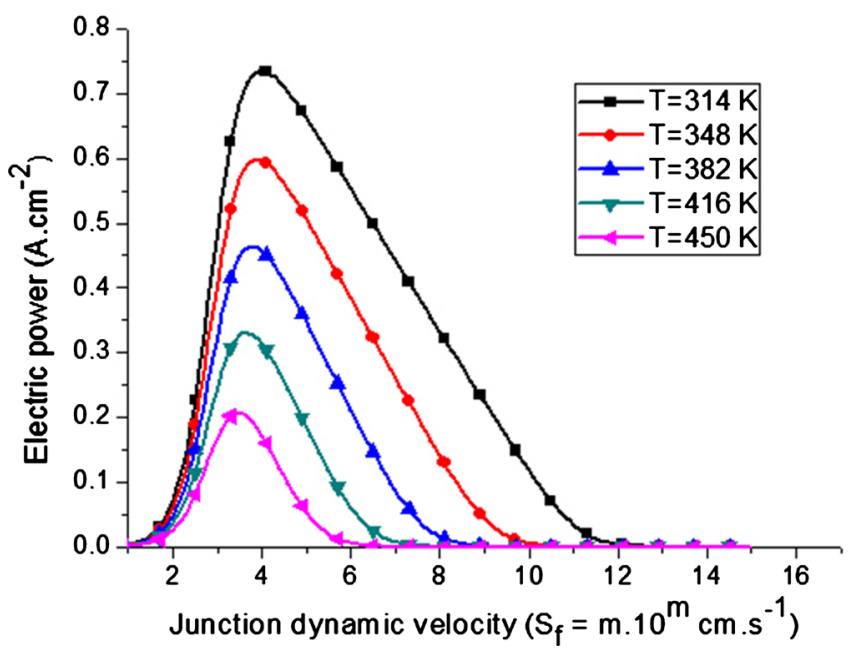

Figure 6. Electric power versus junction dynamic velocity for different values of temperature ( $C=50$ Suns, $H=0.03 \mathrm{~cm}, S_{b}=10^{2} \mathrm{~cm} / \mathrm{s}$ ).

of the maximum power. This result is in agreement with increase of photocurrent density and the significant decrease of photovoltage with temperature increase. This result is in agreement with those of Leye et al. [15], Chander et al. [16] and Agroui et al. [17].

The curves also show a displacement of the maximum power point towards low values of junction dynamic velocity (open-circuit).This displacement of the maximum power point towards open-circuit can be explained by the displacement of the operating point towards open circuit when temperature increases and which was shown by the study of photovoltage.

\subsection{Temperature Effect on Conversion Efficiency}

We give in Table 2 for different temperature, the values of the maximum power, the junction dynamic velocity at maximum power point $\left(S f_{M P P}\right)$ and the solar cell conversion efficiency.

Table 2. Maximum power, the junction dynamic velocity at MPP and conversion efficiency for different temperatures.

\begin{tabular}{cccccc}
\hline$T(K)$ & 314 & 348 & 382 & 416 & 450 \\
$P_{\max }\left(\mathrm{mW} / \mathrm{cm}^{2}\right)$ & 734.46 & 598.79 & 464.06 & 331.20 & 206.89 \\
$S f_{M P P}(\mathrm{~cm} / \mathrm{s})$ & $4.00 \times 10^{4}$ & $3.10 \times 10^{4}$ & $2.40 \times 10^{4}$ & $1.43 \times 10^{4}$ & $1.11 \times 10^{4}$ \\
Efficiency $\eta(\%)$ & 20.40 & 16.63 & 12.89 & 9.20 & 5.74 \\
\hline
\end{tabular}

The results confirm a decrease of maximum power and junction dynamic velocity at maximum power point $\left(S f_{M P P}\right)$ when temperature increases. Table 2 also shows a significant decrease of conversion efficiency with increasing temperature. This decrease of conversion efficiency is explained by the decrease of maximum power. This results trough out also the need to use a cooling system for solar cells under intense light concentration. 


\section{Conclusions}

A one-dimensional study of temperature effect on light-concentrating solar cell was carried out. This study takes into account the electric field of electrons concentration gradient. Temperature effects on diffusion and mobility of electrons and holes, on electrons intrinsic concentration, on carrier's generation rate as well as on width of band gap have also been taken into account.

Thus, under light concentration with taking into account of electrons concentration gradient electric field, it makes possible to show that an increase of temperature improves the diffusion parameters, thus causing a increase of short-circuit photocurrent density.

However, an increase of temperature adversely affects performances of the solar cell. Thus, there is a significant decrease in open-circuit photovoltage, maximum electric power and conversion efficiency when the temperature increases. These results are in agreement with several authors [15] [16] [17] despite the fact that they worked under non-concentrated light and with relatively lower temperature values.

It also appears that an increase of temperature causes a displacement of operating point and maximum power point towards the open circuit. These results confirm the need to use a cooling system for solar cells under intense light concentration.

However in this article, light concentration has been set at $C=50$ Suns, while it could vary and therefore influence the temperature values and the results of this work. It would therefore be interesting to vary the concentration, in order to show for different values of light concentration, how the temperature acts on the solar cell.

\section{Acknowledgements}

The ISP, Uppsala University, Sweden is gratefully acknowledged for their support to project BUF01.

\section{Conflicts of Interest}

The authors declare no conflicts of interest regarding the publication of this paper.

\section{References}

[1] Royne, A., Dey, C.J. and Mills, D.R. (2005) Cooling of Photovoltaic Cells under Concentrated Illumination: A Critical Review. Solar Energy Materials \& Solar Cells, 86, 451-483. https://doi.org/10.1016/j.solmat.2004.09.003

[2] El Chaar, L., Lamont, L.A. and El Zein, N. (2011) Review of Photovoltaic Technologies. Renewable and Sustainable Energy Reviews, 15, 2165-2175. https://doi.org/10.1016/j.rser.2011.01.004

[3] Dimroth, F., Grave, M., Beutel, P., Fiedeler, U., Karcher, C., Tibbits, T.N.D., Oliva, E., Siefer, G., Schachtner, M., Wekkeli, A., Bett, A.W., Krause, R., Piccin, M.T., Blanc, N., Drazek, C.T., Guiot, E., Ghyselen, B., Salvetat, T., Tauzin, A., Signamar- 
cheix, T., Dobrich, A., Hannappel, T. and Schwarzburg, K. (2014) Wafer Bonded Four-Junction GaInP/GaAs//GaInAsP/GaInAs Concentrator Solar Cells with 44.7\% Efficiency. Progress in Photovoltaics: Research and Applications, 22, 277-282. https://doi.org/10.1002/pip.2475

[4] Schachtner, M., Prado, M.L., Reichmuth, S.K., Siefer, G. and Bett, A.W. (2016) Analysis of a Four Lamp Flash System for Calibrating Multi-Junction Solar Cells under Concentrated Light. AIP Conference Proceedings, 1679, Article ID: 050012. https://doi.org/10.1063/1.4931533

[5] Tibbits, T.N.D., Beutel, P., Grave, M., Karcher, C., Oliva, E., Siefer, G., Wekkeli, A., Schachtner, M., Dimroth, F., Bett, A.W., Krause, R., Piccin, M., Blanc, N., Munoz-Rico, M., Arena, C., Guiot, E., Charles-Alfred, C., Drazek, C., Janin, F., Farrugia, L., Hoarau, B., Wasselin, J., Tauzin, A., Signamarcheix, T., Hannappel, T., Schwarzburg, K. and Dobrich, A. (2014) New Efficiency Frontiers with Wafer-Bonded Multi-Junction Solar Cells. 29th European PV Solar Energy Conference and Exhibition, Amsterdam, The Netherlands, 22-26 September 2014, 1975-1978.

[6] Pelanchon, F., Sudre, C. and Moreau, Y. (1992) Solar Cells under Intense Light Concentration: Numerical and Analytical Approaches. 11 th European Photovoltaic Solar Energy Conference, Montreux, 12 -16 October 1992, 265-267.

[7] Zoungrana, M., Zerbo, I., Barro, F.I., Sam, R., Touré, F., Samb, M.L. and Zougmoré, F. (2011) Modélisation à 3-D de l'influence de la taille des grains et de la vitesse de recombinaison aux joints de grain sur une photopile au silicium polycristallin sous éclairement concentré. Revue des Energies Renouvelables, 14, 649-664.

[8] Zoungrana, M., Zerbo, I., Savadogo, M., Tiedrebeogo, S., Soro, B. and Bathiebo, D. J. (2017) Effect of Light Intensity on the Performance of Silicon Solar Cell. Global Journal of Pure and Applied Sciences, 23, 123-129.

https://doi.org/10.4314/gjpas.v23i1.12

[9] Savadogo, M., Zoungrana, M., Zerbo, I., Soro, B. and Bathiebo, D.J. (2017) 3-D Modeling of Grains Sizes Effects on Polycrystalline Silicon Solar Cell under Intense Light Illumination. SYLWAN English Edition, 161, 2-13.

[10] Souza, J.S.T. and De Sousa, N.C.A. (2019) Temperature Influence on Mobility and Charge Density Model of Photovoltaic Cells. Revista Brasileira de Ensino de Física, 41, e20180272. https://doi.org/10.1590/1806-9126-rbef-2018-0272

[11] Nair, K.K., Jose, J. and Ravindran, A. (2016) Analysis of Temperature Dependent Parameters on Solar Cell Efficiency Using MATLAB. IJEDR, 4, 536-541.

[12] Reggiani, S., Valdinoci, M., Colalongo, L., Rudan, M. and Baccarani, G. (2000) An Analytical, Temperature-Dependent Model for Majority- and Minority-Carrier Mobility in Silicon Devices. VLSI Design, 10, 467-483. https://doi.org/10.1155/2000/52147

[13] Ravindra, N.M. and Srivastava, V.K. (1979) Temperature Dependence of the Energy Gap in Semiconductors. Journal of Physics and Chemistry of Solids, 40, 791-793. https://doi.org/10.1016/0022-3697(79)90162-8

[14] Azimi-Nam, S. and Farhani, F. (2017) Effect of Temperature on Electrical Parameters of Phosphorous Spin-On Diffusion of Polysilicon Solar Cells. Journal of Renewable Energy and Environment, 4, 41-45.

[15] Leye, S.N., Fall, I., Mbodji, S., Sow, P.L.T. and Sissoko, G. (2018) Analysis of T-Coefficients Using the Columnar Cylindrical Orientation of Solar Cell Grain. Smart Grid and Renewable Energy, 9, 43-56. https://doi.org/10.4236/sgre.2018.93004

[16] Chander, S., Purohit, A., Sharma, A., Arvind, Nehra, S.P. and Dhaka, M.S. (2015) A 
Study on Photovoltaic Parameters of Mono-Crystalline Silicon Solar Cell with Cell Temperature. Energy Reports, 1, 104-109. https://doi.org/10.1016/j.egyr.2015.03.004

[17] Agroui, K. (1999) Etude du Comportement Thermique de Modules Photovoltaïques de Technologie Monoverre et Biverre au Silicium Cristallin. Revue des Energies Renouvelables (Valorisation), 1, 7-11.

[18] Sy, K.M., Diene, A., Tamba, S., Diouf, M.S., Diatta, I., Dieye, M., Traore, Y. and Sissoko, G. (2016) Effect of Temperature on Transient Decay Induced by Charge Removal of a Silicon Solar Cell under Constant Illumination. Journal of Scientific and Engineering Research, 3, 433-445.

[19] Mané, R., Diallo, H.L., Ba, H., Diatta, I., Traoré, Y., Sarr, C.T. and Sissoko, G. (2018) Influence of Both Magnetic Field and Temperature on Silicon Solar Cell Photogenerated Current. Journal of Scientific and Engineering Research, 5, 241-251.

[20] Dubey, S., Sarvaiya, J.N. and Seshadri, B. (2013) Temperature Dependent Photovoltaic (PV) Efficiency and Its Effect on PV Production in the World-A Review. Energy Procedia, 33, 311-321. https://doi.org/10.1016/j.egypro.2013.05.072

[21] Soro, B., Zoungrana, M., Zerbo, I., Savadogo, M. and Bathiebo, D.J. (2017) 3-D Modeling of Temperature Effect on a Polycrystalline Silicon Solar Cell under Intense Light Illumination. Smart Grid and Renewable Energy, 8, 291-304. https://doi.org/10.4236/sgre.2017.89019

[22] Wang, Z., Zhang, H., Zhao, W., Zhou, Z. and Chen, M. (2015) The Effect of Concentrated Light Intensity on Temperature Coefficient of the InGaP/InGaAs/Ge Triple-Junction Solar Cell. The Open Fuels and Energy Science Journal, 8, 106-111.

[23] Dieme, N., Seibou, B., Ould El Moujtaba, M.A., Gaye, I. and Sissoko, G. (2015) Thermal Behavior of a Parallel Vertical Junction Silicon Photocell in Static Regime by Study of the Series and Shunt Resistances under the Effect of Temperature. International Journal of Innovative Science, Engineering \& Technology (IISET), $2,1$.

[24] Sahin, G. (2016) Effect of Temperature on the Series and Shunt Resistance of a Silicon Solar Cell under Frequency Modulation. Journal of Basic and Applied Physics, 5, 21-29. https://doi.org/10.5963/JBAP0501003

[25] Zerbo, I., Zoungrana, M., Seré, A.D. and Zougmoré, F. (2012) Silicon Solar Cell Under Electromagnetic Wave in Steady State: Effect of the Telecommunication Source's Power of Radiation. IOP Conference Series. Materials Science and Engineering, 29, Article ID: 012019. https://doi.org/10.1088/1757-899X/29/1/012019

[26] Diouf, A., Savadogo, M. and Mbodji, S. (2018) External Quantum Efficiency (EQE) and Internal Quantum Efficiency (IQE) in a 3D Cylindrical Modeling Study. Journal of Scientific and Engineering Research, 5, 125-132. 